Article

\title{
Doping $\beta$-TCP as a Strategy for Enhancing the Regenerative Potential of Composite $\beta$-TCP-Alkali-Free Bioactive Glass Bone Grafts. Experimental Study in Rats
}

\author{
Manuel M. Ferreira ${ }^{1,2}$, Ana F. Brito ${ }^{1,3,4}$, Daniela Brazete ${ }^{5}$, Inês C. Pereira ${ }^{5}$, Eunice Carrilho ${ }^{1,2,6}$, \\ Ana M. Abrantes ${ }^{1,2,4}$, Ana S. Pires ${ }^{1,2,4}{ }^{1}$, Maria J. Aguiar ${ }^{7}$, Lina Carvalho ${ }^{2,7}$, \\ Maria F. Botelho ${ }^{1,2,4}$ and José M.F. Ferreira ${ }^{5, *(D)}$ \\ 1 Coimbra Institute for Clinical and Biomedical Research (iCBR) area of Environment Genetics and \\ Oncobiology (CIMAGO), Faculty of Medicine, University of Coimbra, 3000-548 Coimbra, Portugal; \\ m.mferreira@netcabo.pt (M.M.F.); ana.brito@reg4life.com (A.F.B.); eunicecarrilho@gmail.com (E.C.); \\ mabrantes@fmed.uc.pt (A.M.A.); a.salome.pires@gmail.com (A.S.P.); mfbotelho@fmed.uc.pt (M.F.B.) \\ 2 Faculty of Medicine, University of Coimbra, 3000-548 Coimbra, Portugal; lcarvalho@huc.min-saude.pt \\ 3 OssMed-Regeneration Technology, Biocant - Ass de Transf. de Tecnologia, Pq Tecnológico de Cantanhede, \\ Núcleo 04, Lote 3, 3060-197 Cantanhede, Portugal; contact@ossmed.eu \\ 4 Biophysics and Biomathematics Institute, IBILI-Faculty of Medicine of University of Coimbra, \\ 3000-548 Coimbra, Portugal \\ 5 Department of Materials and Ceramic Engineering, CICECO, University of Aveiro, Campus Santiago, \\ Aveiro, 3810-193 Aveiro, Portugal; d.s.b@live.ua.pt (D.B.); icarolina@live.ua.pt (I.C.P.); jmf@ua.pt (J.M.F.F.) \\ 6 Institute of Integrated Clinical Practice, Faculty of Medicine, University of Coimbra, \\ 3000-548 Coimbra, Portugal \\ 7 Institute of Pathological Anatomy, Faculty of Medicine, University of Coimbra, 3000-548 Coimbra, Portugal; \\ iap@fmed.uc.pt \\ * Correspondence: jmf@ua.pt; Tel.: +351-234-370242
}

Received: 14 November 2018; Accepted: 13 December 2018; Published: 20 December 2018

\begin{abstract}
The present work aims at evaluating the potential gains derived from partially replacing calcium in resorbable $\beta$-tricalcium phosphate $(\beta$-TCP) by two different molar percentages of strontium $(5,10)$ and zinc $(1,2)$, concomitantly with a fixed molar percentage $(0.5)$ of manganese. Synthetic granular composite bone filling grafts consisting of doped $\beta$-TCP and an alkali-free bioactive glass were prepared and implanted in $\sim 4 \mathrm{~mm}$ diameter bone defects drilled in the calvaria of Wistar rats used as animal models. The animals were sacrificed after 9 weeks of implantation and the calvaria was excised. Non-manipulated bone was used as positive control, while empty defects were used as a negative control group. The von Kossa staining revealed an enhanced new bone formation with increasing doping levels, supporting the therapeutic effects exerted by the doping elements. The percentage of newly formed bone was similar when the defects were filled with autologous bone, BG (previous results) or 3TCP2/7BG, which indicates that the latter two are excellent candidates for replacement of autologous bone as bone regeneration material. This finding confirms that doping with suitable doses of therapeutic ions is a good strategy towards transposing the bone graft materials to biomedical applications in humans.
\end{abstract}

Keywords: composite bone grafts; calcium phosphates; implants; dentistry; biomedical engineering; osteogenesis 


\section{Introduction}

Problems associated with the skeletal system affect millions of people around the world, especially in people over fifty years old. Fractures related to osteoporosis, severe injuries, different types of diseases and bone disabilities are among the various causes of chronic pain and bone loss, leading to morbidity and mortality of hundred millions of people [1]. Several types of bone graft materials have been used to restore damaged bones, including different types of calcium phosphates (CaPs) and biodegradable materials [2,3] in a variety of forms such as powders [4], scaffolds [5] and cements [6]. The similar chemical composition of CaPs to the inorganic part of hard tissues is considered as an advantage that justifies their selection for applications in orthopedics [7], dentistry [8,9], repair of fractures, cranium-maxillofacial reconstruction, spinal surgery, and ophthalmology [10].

An ideal bone substitute must be biocompatible, osteconductive to enable osseointegration, and osteoinductive to stimulate the mesenchymal stem cells to differentiate in bone-forming cells [11,12], Additionally, they must also undergo the degradation and resorption processes in vivo $[13,14]$. These relevant characteristics have been identified in several studies dealing with $\mathrm{CaPs}$ such as $\beta$-tricalcium phosphate $\left(\mathrm{Ca}_{3}\left(\mathrm{PO}_{4}\right)_{2}, \beta-\mathrm{TCP}\right)$ [15-21] and hydroxyapatite $\left(\mathrm{Ca}_{10}\left(\mathrm{PO}_{4}\right)_{6}(\mathrm{OH})_{2}, \mathrm{HA}\right)[15-17,19]$. The biodegradation mechanisms and resorption behavior in vivo of CaPs materials intended for bone repair and tissue engineering applications were recently reviewed $[3,13]$. Similarly, a number of other recent literature reports provide interesting evidence about the in vitro and in vivo performance of alkali-free bioactive glasses (BGs) [22-27].

The mineral part of the bone consists of inorganic salts and crystals [28]. Synthetic HA and $\beta-\mathrm{TCP}$ are prone to incorporate some trace doping elements into the crystalline lattices. Some trace elements existing in bone composition play essential roles in bone formation, growth and repair. Strontium (Sr), zinc $(\mathrm{Zn})$ and manganese $(\mathrm{Mn})$ are some of the most beneficial doping elements [28,29] commonly used to improve the physicochemical properties of the biomaterials [30]. The replacement of $\mathrm{Ca}^{2+}$ by $\mathrm{Sr}^{2+}$ in the crystalline structures of incorporation of HA and $\beta$-TCP enhanced the solubility of CaPs [31] stimulated osseointegration [32]. Preventing osteoporosis by reducing reabsorption by osteoclasts and consequently increasing bone formation and the mechanical resistance of the hard tissues, thus reducing the risk of bone fractures are other important benefits commonly reported [21,33,34]. Zinc plays an important role in bone metabolism [32], stimulating bone formation and regeneration, while improving bone mineralization [35-38] and cell adhesion [39]. Other studies showed that Zn-doping endows the bioactive bone grafts with anti-inflammatory activity [40]. This is of paramount importance to inhibit bacterial growth and biofilm formation and, therefore, for preventing infections at the surgical site, thus stimulating wound healing [41,42]. Manganese plays an important role as cofactor for several enzymes that are involved in extracellular matrix remodeling. It is also of great importance with regard to the binding affinity of integrins, receptors mediating the cellular interactions and promoting cell adhesion [43-45]. Previous in vitro studies have shown that low levels of Mn-doping in $\beta$-TCP powders exerted several stimuli towards a pre-osteoblastic cell line viability, proliferation and differentiation [46].

The ability of BGs to establish direct and strong chemical bonds with bone and soft tissues was

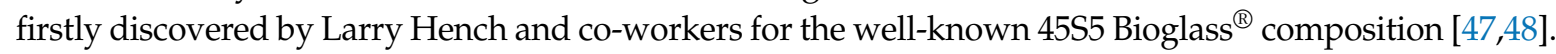
However, the high dissolution and degradation rates of 4555 Bioglass ${ }^{\circledR}$, mostly derived from its high alkali content (>24 mol\%) [49,50] are often pointed out as some drawbacks. Moreover, 45S5 Bioglass ${ }^{\circledR}$ hardly can be used for the fabrication of porous structures used as scaffolds for applications in bone regeneration and tissue engineering. As a matter of fact, the readiness to crystalize due to the extremely poor sintering ability, brings serious drawbacks in terms of mechanical properties [51-54]. These limitations can be overcome by using alkali free BGs $[23-25,27,55,56]$ that possess several advantages listed in the Table 1. An alkali-free BG composition designed in the ternary system and consisting of (wt. $\%$ ): 70 diopside (Di-CaMgSi ${ }_{2} \mathrm{O}_{6}$ )-20 tricalcium phosphate (TCP-3CaOP ${ }_{2} \mathrm{O}_{5}$ )-10 fluorapatite $\left(\mathrm{FA}-\mathrm{Ca}_{5}\left(\mathrm{PO}_{4}\right)_{3} \mathrm{~F}\right)$ was selected. This composition was shown to exhibit a fast bio-mineralization rate, with the formation of a carbonated hydroxyapatite (HCA) surface layer after $1 \mathrm{~h}$ of immersion in 
simulated body fluid (SBF) being detected by XRD and FTIR analyses [23]. Since the bone bonding to living tissues is mediated by this HCA layer, this bioactive glass composition was suggestively designated as FastOs ${ }^{\circledR} \mathrm{BG}$ to give a due account of this particular feature.

Table 1. Features of the alkali-free FastOs ${ }^{\circledR} \mathrm{BG}$.

\begin{tabular}{cc}
\hline Features & References \\
\hline Moderate degradation rate and fast bio mineralization in vitro, with HA formation & {$[23,56,57]$} \\
detected after 1 h of immersion in simulated body fluid (SBF) & {$[56,57]$} \\
Ability to reduce oxidative stress & {$[24]$} \\
Excellent bone bonding ability in vivo & {$[26]$} \\
Osteogenic ability & {$[25,58]$} \\
Excellent sintering behavior & {$[25,58]$} \\
Strong mechanical properties & {$[59]$} \\
\hline
\end{tabular}

It was also demonstrated that FastOs ${ }^{\circledR} \mathrm{BG}$ could induce and stimulate the differentiation of human mesenchymal stem cells (hMSCs) into bone-forming cells, even under the less favorable conditions (absence of osteogenic medium) [27]. When FastOs ${ }^{\circledR} \mathrm{BG}$ was implanted in sheep as animal model it also revealed an excellent in vivo accomplishment [24] in comparison to $45 \mathrm{S5}$ Bioglass ${ }^{\circledR}$ used as control. In another recent study [22], the in vivo performances of FastOs ${ }^{\circledR} \mathrm{BG}$ used as single material, or mixed with pure $\beta$-TCP were compared with each other, and with a commercial granular product, (adbone ${ }^{\circledR} \mathrm{BCP}$ ) supplied by Medbone ${ }^{\circledR}$, Sintra Portugal. This last bone graft material is a biphasic calcium phosphate allegedly containing $75 \%$ of HA and $25 \%$ of $\beta$-TCP. The bone graft materials implanted in calvaria Wistar rats enabled to conclude that FastOs ${ }^{\circledR} \mathrm{BG}$ alone gave the most interesting biological response among all the tested materials.

The aptitude of calcium phosphates as bone graft materials is very well-known and extensively documented $[6,7,14,18,28,29,36,43,57,60]$. Considering the potential benefits of doping elements in terms of the in vitro and in vivo performances, the present work aims at replacing the pure $\beta$-TCP in the composite mixtures by doped $\beta$-TCP powders and investigating if doping could bring further advantages in terms of bone regeneration in comparison to the non-doped counterpart. Powders of $\beta$-TCP with two molar concentrations of different doping elements: $\operatorname{Sr}(5,10), \mathrm{Zn}(1,2)$, and a fixed amount of $\mathrm{Mn}(0.5)$ were prepared. Non-manipulated bone and the composite containing pure $\beta$-TCP were used as control materials.

\section{Materials and Methods}

\subsection{Preparation of the Starting Metal-Doped $\beta$-TCP and FastOs ${ }^{\circledR} B G$ Powders}

The $\beta$-TCP powders non-doped (TCP0) and doped with Sr, Zn and Mn ions were synthetized via wet chemical precipitation. The concentrations of the precursors were chosen in order to obtain a total $(\mathrm{Ca}+\mathrm{Sr}+\mathrm{Zn}+\mathrm{Mn}) / \mathrm{P}$ molar ratio of 1.5. The different dopant concentrations selected were as follows: $\beta$-TCP1 (5, 1, and $0.5 \mathrm{~mol} \%$ of Sr, Zn and Mn, respectively) (TCP1); and $\beta$-TCP2 (10, 2 and $0.5 \mathrm{~mol} \%$ of $\mathrm{Sr}, \mathrm{Zn}$ and $\mathrm{Mn}$, respectively) (TCP2). For this purpose, analytical grade precursor reagents were combined in the required molar percentages. The following precursors were used: calcium nitrate tetrahydrate $\left(\mathrm{Ca}\left(\mathrm{NO}_{3}\right)_{2} 4 \mathrm{H}_{2} \mathrm{O}\right.$, Quality Chemicals, Barcelona, Spain) for $\mathrm{Ca}$, diammonium hydrogen phosphate $\left(\left(\mathrm{NH}_{4}\right)_{2} \mathrm{HPO}_{4}\right.$, Quality Chemicals, Barcelona, Spain) for $\mathrm{P}$, strontium nitrate $\left(\mathrm{Sr}\left(\mathrm{NO}_{3}\right)_{2}\right.$, Sigma-Aldrich, Darmstadt Germany) for $\mathrm{Sr}$, zinc nitrate hexahydrate $\left(\mathrm{Zn}\left(\mathrm{NO}_{3}\right)_{2} 6 \mathrm{H}_{2} \mathrm{O}\right.$, Sigma-Aldrich, Darmstadt, Germany) for $\mathrm{Zn}$, and manganese(II) nitrate hydrate $\left(\mathrm{Mn}\left(\mathrm{NO}_{3}\right)_{2} \times \mathrm{XH}_{2} \mathrm{O}\right.$, Sigma-Aldrich, Darmstadt, Germany) for Mn. The stock solutions containing the cationic and anionic species were prepared separately. After total dissolution of the precursors, the phosphate solution was drop wisely added to the cationic solution. The $\mathrm{pH}$ of the mixture was maintained at $\sim 7$ by carefully adding the 
required amounts of concentrated ammonium hydroxide $\left(\mathrm{NH}_{4} \mathrm{OH}\right)$ solution. The reaction was carried out for $3 \mathrm{~h}$ under controlled temperature and stirring conditions $\left(30^{\circ} \mathrm{C}, 1000 \mathrm{rpm}\right)$.

The obtained solid precipitate was then separated from the supernatant solution through vacuum filtration and dried overnight in an oven at $100{ }^{\circ} \mathrm{C}$. The dried powder was deagglomerated using a mortar and pestle and then calcined at $800{ }^{\circ} \mathrm{C}$ for $2 \mathrm{~h}$. After calcination, the powder was deagglomerated by ball milling as reported elsewhere [60].

The FastOs ${ }^{\circledR} \mathrm{BG}$ composition (38.49 $\mathrm{SiO}_{2}-5.61 \mathrm{P}_{2} \mathrm{O}_{5}-36.07 \mathrm{CaO}-19.24 \mathrm{MgO}-0.59 \mathrm{CaF}_{2}$, in $\mathrm{mol}_{\%}$ ), was prepared by the melt-quenching route [20]. The batches $(\sim 100 \mathrm{~g})$ were prepared by combining appropriate amounts of high purity silica (purity $>99.5 \%$ ), and precursor reagents for




325 mesh, >99.9\%). The batches were thoroughly mixed and homogenized by ball milling during $30 \mathrm{~min}$ and then decarbonated by heating at a rate of $5^{\circ} \mathrm{C} \min ^{-1}$ up to $900{ }^{\circ} \mathrm{C}$, followed by $1 \mathrm{~h}$ dwell time at this temperature. The melting of the batches was performed in a Pt-10Rh crucible at $1570-1590{ }^{\circ} \mathrm{C}$ for $1 \mathrm{~h}$ using the same heating rate of $5{ }^{\circ} \mathrm{C} \mathrm{min}^{-1}$. The molten glass was then quenched by pouring it in cold water to obtain the glass frit. Afterwards, the frit was dried in an oven at $100{ }^{\circ} \mathrm{C}$ and then milled in a high-speed agate mill for the time required to obtain a powder with a mean particle size $\leq 10 \mu \mathrm{m}$. The milled FastOs ${ }^{\circledR} \mathrm{BG}$ frit revealed to be completely amorphous. The crystalline phases of non-doped and ( $\mathrm{Sr}, \mathrm{Zn}, \mathrm{Mn}$ )-doped $\beta$-TCP powders were determined by $\mathrm{X}$-ray powder diffraction (XRD) analysis (X'Pert PRO PANalytical, Almelo, Netherlands) and Fourier Transform Infrared Spectrometry (FT-IR) model Bruker Tensor 27 FT-IR; Bruker, Billerica, MA, United States).

\subsection{Preparation of Porous Granular Composite Bone Grafts}

Porous granular composites consisting of $3 / 7$ volume ratio between the different calcium phosphate components ( $\beta$-TCPn, $n=0,1,2)$, and FastOs ${ }^{\circledR} B G$ were prepared according to the procedure reported elsewhere [22]. Table 2 presents the detailed description of the individual components, the composite materials prepared therefrom, and their respective sample codes. These short names will be hereafter preferably used throughout the manuscript.

Table 2. Detailed description of the samples, and their respective codes.

\begin{tabular}{cc}
\hline Description of the Samples & Codes of the Samples \\
\hline Component materials & \\
$\beta$-TCP non-doped & TCP0 \\
$\beta-\mathrm{TCP}$ doped with $5 \mathrm{Sr}, 1 \mathrm{Zn}, 0.5 \mathrm{Mn}(\mathrm{mol} \%)$ & $\mathrm{TCP} 1$ \\
$\beta-\mathrm{TCP}$ doped with $10 \mathrm{Sr}, 2 \mathrm{Zn}, 0.5 \mathrm{Mn}(\mathrm{mol} \%)$ & $\mathrm{TCP} 2$ \\
FastOs ${ }^{\circledR} \mathrm{BG}$ & \\
Composites $($ volume ratio) & $3 \mathrm{TCP} 0 / 7 \mathrm{BG}$ \\
$3 \beta-\mathrm{TCP} 0 / 7 \mathrm{FastOs}{ }^{\circledR} \mathrm{BG}$ & $3 \mathrm{TCP} 1 / 7 \mathrm{BG}$ \\
$3 \beta-\mathrm{TCP} 1 / 7 \mathrm{FastOs}{ }^{\circledR} \mathrm{BG}$ & $3 \mathrm{TCP} 2 / 7 \mathrm{BG}$ \\
$3 \beta-\mathrm{TCP} 2 / 7 \mathrm{FastOs}{ }^{\circledR} \mathrm{BG}$ & \\
Control groups used in the in vivo experiments \\
Non-manipulated bone (Positive control) \\
Empty defect (Negative control) \\
Bone-filled defect \\
FastOs ${ }^{\circledR} \mathrm{BG}$
\end{tabular}

Suspensions containing a $3 / 7$ volume ratio of $(\beta-\mathrm{TCPn}, \mathrm{n}=0,1,2) /$ FastOs ${ }^{\circledR} \mathrm{BG}$ and a total solid loading of $60 \mathrm{vol} . \%$ were prepared by adding $0.4 \mathrm{wt} . \%$ of Targon 1128 as dispersing agent. TRECOMEX AET1 (Starkelsen Lyckeby AB, Blaklycke Jämjö Sweden—esterified potato starch with an average grain size of about $55 \mu \mathrm{m}$ ) was added as pore former agent in the same volume fraction as inorganic solids. The as-obtained suspensions were then mixed with a $3 \mathrm{wt} . \%$ sodium alginate solution (Sigma-Aldrich, Darmstadt, Germany) at the weight ratio of 0.8 . The as-prepared mixtures were kept under stirring 
until reach complete homogenization. Afterwards, spherical granules were obtained by dropping the homogenized suspension into the setting $\mathrm{CaCl}_{2}$ solution. A spraying system consisting of a peristaltic pump (505S; Watson Marlow, Falmouth Cornwal, England) adjusted for a suspension flow rate of $9 \mathrm{rpm}$ through a $1.5 \mathrm{~mm}$ nozzle diameter under a constant air pressure of 0.8 bar was used. The granules generated by the gradual gelation of sodium alginate with the $\mathrm{Ca}^{2+}$ ions were maintained in $\mathrm{CaCl}_{2}$ solution for about $10 \mathrm{~min}$ to allow their complete consolidation. The as-obtained granules were then separated from the solution by sieving, dried overnight at $80^{\circ} \mathrm{C}$, and then heat-treated to burnout the organics, and sintering at $800^{\circ} \mathrm{C}$. Considering that burnout of the organics is a slow process, a heating rate of $1{ }^{\circ} \mathrm{C} \mathrm{min}^{-1}$ was used within the corresponding temperature range of $250-500{ }^{\circ} \mathrm{C}$. The first and the last heat treatment steps up to $250{ }^{\circ} \mathrm{C}$, and from $500-800{ }^{\circ} \mathrm{C}$, respectively, were both conducted at the heating rate of $5{ }^{\circ} \mathrm{C} \mathrm{min}-1$ up to $800{ }^{\circ} \mathrm{C}$. After a dwell time of $2 \mathrm{~h}$ at $800{ }^{\circ} \mathrm{C}$, the furnace has been turned off, followed by natural cooling to RT as reported elsewhere [22]. The obtained granules were finally sterilized by autoclaving and safely packed before implantation.

\subsection{XRD, FT-IR and Particle Size Distribution Analyses}

A qualitative phase analysis of the inorganic powders was performed by X-ray diffraction. For this, a high-resolution X-ray diffractometer (X'Pert PRO PANalytical, Almelo, Netherlands)) equipped with Ni-filtered $\mathrm{CuK} \alpha$ radiation $(\lambda=1.54056 \AA)$ was used to collect the $X$-ray diffraction data within the $2 \theta$ range of $5-110^{\circ}$ using a step size $0.02^{\circ}$ and $96 \mathrm{~s}$ of counting time for each step. The ICDD cards numbers \# 040069376 for $\beta$-TCP and \# 040093876 for $\beta$-CCP were used as models for identifying the crystalline phases.

Infrared spectra were obtained by FT-IR (model Bruker Tensor 27 FT-IR; Bruker, Billerica, MA, USA). Each starting powder was mixed with $\mathrm{KBr}$ in the proportion of $1 / 150$ (by weight) for $15 \mathrm{~min}$ and pressed into a pellet. Each infrared spectrum was the average of 128 scans collected at $4 \mathrm{~cm}^{-1}$ resolution at room temperature (RT).

Particle size distribution (PSD) and the average particle size (PS) of the powder were assessed using a laser diffraction particle size analyzer (COULTER LS230, Northewell Drive, Luton, England, Fullerton CA-Fraunhofer optical model).

\subsection{Surgical Procedure}

The regenerative potential of the different granules prepared was evaluated by animal experiments, using Wistar rats as an animal model (Figure 1). This study was performed according to the Declaration of Helsinki and in accordance with guidelines of the Portuguese Society of Animal Science Laboratory and of the Council for International Organization of Medical Sciences Ethical Code for Animal Experimentation. The study was approved by the Ethical Committee of the Faculty of Medicine of University of Coimbra, Coimbra, Portugal (protocol number: 005-CE-2014). In this study, ten thirteen-week old Wistar rats were used.

On the day of surgery (day 0 ) the rats were anesthetized by intraperitoneal administration of chlorpromazine (Largactil ${ }^{\circledR}$, Laboratórios Vitória, Amadora 2700-326, Portugal) plus ketamine (Ketalar®, Pfizer, 2740-244 Porto Salvo, Portugal) 1:3 (0.1 mL/20 g) solution. A trichotomy of the skull cap was then performed, and the region was disinfected with povidone-iodine. A longitudinal incision with $3 \mathrm{~cm}$ was made with a scalpel \# 12 to expose the calvaria bone. Then, on each side of the cranium, two bone defects of approximately $4.4 \mathrm{~mm}$ diameter were performed using a trephine bur with $4 \mathrm{~mm}$ of diameter and a motor with $5000 \mathrm{rpm}$ under constant irrigation with saline solution (Solução isotónica de Cloreto de Sódio, Paracélsia, Indústria Farmacêutica, S.A. Porto, Portugal).

Five experimental groups were formed. The non-manipulated bone was used as positive control. The bone defect not filled (empty) was used as the negative control. In the other 3 experimental groups, the bone defects were filled with: $3 \beta-\mathrm{TCP} 0 / 7 \mathrm{FastOs}{ }^{\circledR} \mathrm{BG}, 3 \beta-\mathrm{TCP} 1 / 7 \mathrm{FastOs}{ }^{\circledR} \mathrm{BG}$ or $3 \beta$-TCP2/7FastOs ${ }^{\circledR}$ BG (Figure 1, Table 2). For comparison, the results of autologous bone and BG obtained by us and referred at reference 22 were used. 




Figure 1. (a) Surgical image of the defects created. One defect was empty (negative control group); the other was filled with composite granules shown in (b), (experimental group).

\subsection{Ex Vivo Studies}

The animals were sacrificed 9 weeks after surgery, and calvaria bone samples were excised. After the sacrifice, an incision was performed with a scalpel \#12 in the same location of the previous surgery (day 0) to expose the calvaria bone. After debridement of surrounding soft tissue with a diamond circular cutting blade mounted on a micromotor, 4 perpendicular cuts were made at a sufficient distance from the defects previously created, so that the two defects stay incorporated in the same anatomical piece. A diagonal cut in the distal corner of the left side of the specimen was also made, to enable guiding the sample and identify which side corresponding to each graft substitute used.

\subsection{Direct Digital Radiography}

The excised samples were radiographed using a portable X-ray machine, Port-X II (GENORAY Co. Ltd., 434-6 Sangdaewon-dong, Korea) with an exposure time of $0.04 \mathrm{~s}$ under a voltage of $60 \mathrm{kV}$ and a current intensity of $2 \mathrm{~mA}$. A sensor of cesium iodide crystals Gendex (VixWin Pro, version 1.5, 1910 North Penn Road Hatfield, PA 19440 USA) allows the acquisition of the images, which were visualized in a computer monitor and quantitatively analyzed with ImageJ software (NIH, Bethesda, Bethesda, MD 20814, USA). A region of interest (ROI) chosen in each sample was used to obtain the average density values from each bone defect. As a positive control in this evaluation was also drawn an ROI at a non-manipulated bone site.

\subsection{Histological and Histomorphometric Analysis}

The haematoxylin and eosin (H\&E) staining (histological analysis) was performed to assess inflammatory infiltrate, fibroblastic proliferation and bone formation. In its turn, histomorphometric analysis was used to evaluate and the \% of newly formed bone. Thus, the excised samples were fixed in 10\% formalin during $48 \mathrm{~h}$, and decalcified in Osteomoll (EMD Millipore Corporation, Burlington Massachusetts 01803, USA - rapid decalcifier) for about 3 weeks. Afterwards, the samples were embedded in paraffin, sectioned into $5 \mathrm{~mm}$ thick sections, and then stained with (H\&E) or Von Kossa (VK). The H\&E reveal basophilic structures (nucleus) and acidic structures (cytoplasm), respectively. In turn, the VK staining reveals calcium deposits or salts, being therefore useful to confirm the occurrence of mineralization. After staining, the sections that included the defects were subjected to observation under a light microscope (Nikon Eclipse 80i, Postbus 769211070 KE Amsterdam, the Netherlands) and images were acquired using NIS-Elements software (Nikon Instruments Europe BV Postbus $769211070 \mathrm{KE}$, Amsterdam, the Netherlands). All imaging assessment was performed by a single researcher who was blinded to the sample groups. For histomorphometric measurements Image 
J (NIH, Bethesda, Bethesda, MD 20814, USA) was used to determine the percentage of newly formed bone (NFB), which was calculated as follows:

$$
\mathrm{NFB} \%=((\text { New bone area }) / \mathrm{TDA}) \times 100
$$

where TDA corresponds to the dimensions of total defect area.

\subsection{Statistical Analysis}

Statistical analysis was performed using IBM SPSS software v.23.0 (IBM Corporation, Armonk, NY, USA). Normal distribution was assessed by Shapiro-Wilk test and variance of quantitative variables was ascertained by Levene test. Statistical differences were then determined by ANOVA with post-hoc comparison using Games-Howel test, where for $p<0.05$ the differences were considered statistically significant.

\section{Results and Discussion}

\subsection{Characterization of the Starting Powders}

The XRD patterns of two tricalcium phosphate powders heat treated at $800{ }^{\circ} \mathrm{C}$, one without dopants (TCP0) and the other containing the highest tested concentrations of doping elements (TCP2) are displayed in Figure 2a. The results for TCP1 are not shown as they were very similar to those obtained for TCP2. It can be seen that both TCP0 and TCP2 samples apparently consist of a single crystalline phase corresponding to $\beta-\mathrm{TCP}$, as all XDR peaks show good coincidence with the diffraction lines of the standard ICDD card number \# 04-006-9376 for $\beta$-TCP. The XRD pattern of the FastOs ${ }^{\circledR} B G$ powder frit is also included, demonstrating its complete amorphous nature.


Figure 2. Structural features of the starting powders: (a) XRD patterns; (b) FT-IR spectra.

Other phases such as calcium pyrophosphate (CPP) or HA, when present in amounts below the detection limit, cannot be ruled out by XRD, and their identification requires the use of complementary techniques such as FT-IR. Accordingly, the FT-IR spectra of the TCP powders heat treated at $800^{\circ} \mathrm{C}$ are displayed in Figure $2 \mathrm{~b}$. The results of FT-IR analysis provide further useful information: $a$ 
band at $727 \mathrm{~cm}^{-1}$ appearing in the spectra of both samples is characteristic of the P-O-P bonds, and typical of the $\mathrm{P}_{2} \mathrm{O}_{7}{ }^{4-}$ groups. This band indicates the presence of CPP as minor phase. The presence of bands at $549 \mathrm{~cm}^{-1}, 605 \mathrm{~cm}^{-1}, 941 \mathrm{~cm}^{-1}, 968 \mathrm{~cm}^{-1}$, and a broad band within the 1020 and $1120 \mathrm{~cm}$ textsuperscript-1 [61,62] characteristic of vibrational modes of $\mathrm{PO}_{4}{ }^{3-}$, confirm the formation of the $\beta$-TCP phase as the predominant crystalline phase. The peak $1600 \mathrm{~cm}^{-1}$ is due to adsorbed water and the one at $1384 \mathrm{~cm}^{-1}$ is assigned to carbonate group $\left(\mathrm{CO}_{3}{ }^{2-}\right)[62,63]$. Therefore, the samples consist of $\beta-\mathrm{TCP}$ as the main phase and of CPP as minor secondary phase.

The particle size distribution (PSD) curves of the starting powders are displayed in Figure 3. These curves show both TCP0 and TCP2 powders consist of bimodal PSDs. The fine particle populations are centered at around $0.4 \mu \mathrm{m}$ and are likely constituted by individual particles. The coarser populations are centered at around $3 \mu \mathrm{m}$ and likely represent particle agglomerates incompletely destroyed upon milling. The FastOs ${ }^{\circledR}$ BG powder exhibits a considerably extended PSD with only a single main population. The mean particle sizes of TCP0, TCP2, and FastOs ${ }^{\circledR} \mathrm{BG}$ powder were $1.5 \mu \mathrm{m}, 1.6 \mu \mathrm{m}$, and $7.2 \mu \mathrm{m}$, respectively.

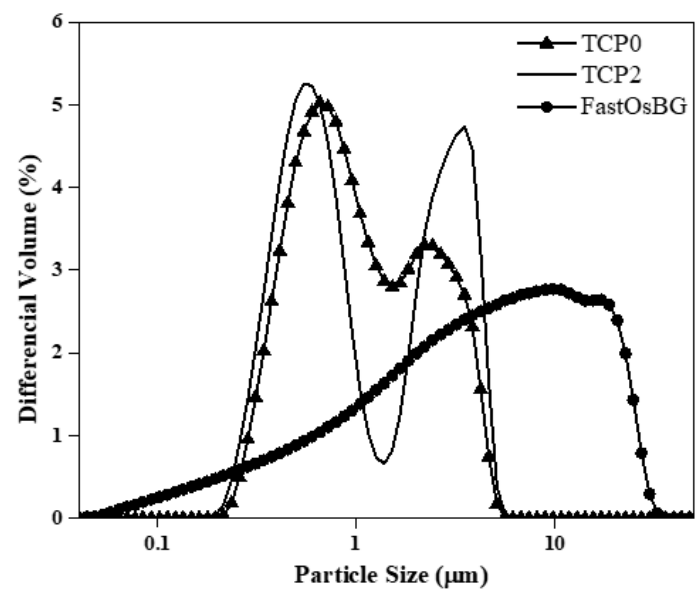

Figure 3. Particle size distributions of the starting TCP0, TCP2 and FastOS ${ }^{\circledR} \mathrm{BG}$ powders after ball milling.

\subsection{Postoperative Animal Care}

After surgery, there were no identified signs of disease, such as: dehydration, apathy, indifference, prostration, dyspnea, moving in circles or head tipping/tilting, as well as signs of abnormal physiological conditions, in diuresis, faeces volume, body mass and decreased food and/or water intake.

\subsection{Digital Radiographic Evaluation}

The radiographic bone density was analyzed by the Image J software. A region of interest (ROI) in each specimen was chosen and the average value of radiographic bone density from each bone defect was obtained (Figure 4). The data of the radiographic bone density was expressed in arbitrary grayscale media and the results gathered for the samples are plotted in Figure 5.

According to Figure 5, statistical significant differences in the radiographic bone density values can be observed between non-filled defect (Empty group) and defects filled with bone $(p<0.05)$, BG $(p<0.05), 3$ TCP0/7BG $(p<0.05), 3$ TCP1/7BG $(p<0.001)$, 3TCP2/7BG $(p<0.001)$, confirming the regenerative potential of the biomaterials tested. It was also observed a statistical significant difference between empty group and positive control, which confirms the almost null bone regeneration capacity of the unfilled defect during the time studied. There are great similarities in the values obtained for defects filled with autologous bone and with the three investigated synthetic composite bone grafts under study. Although there were no statistically significant differences, there was a tendency for an increase in bone density with increasing of dopant contents. This tendency is likely attributed to 
the opacifying effects exerted by the doping elements with higher atomic numbers in comparison to $\mathrm{Ca}=20(\mathrm{Sr}=38 ; \mathrm{Zn}=30, \mathrm{Mn}=25)$. The absence of doping elements on the case of BG sample is also consistent with its slightly inferior radiographic bone density. However, the measured standard deviation values are relatively high, which difficult to obtain precise conclusions about the effects of the doping elements. The reasons for this high variability might be attributed to: (i) the shallow defects drilled in calvaria bone due to its small thickness; (ii) any possible lateral dislocation of the implanted materials as a result of placing the animals in the lateral decubitus position after surgery in order to facilitate breathing. However, a more detailed analysis about the relative importance of each factor is impossible.
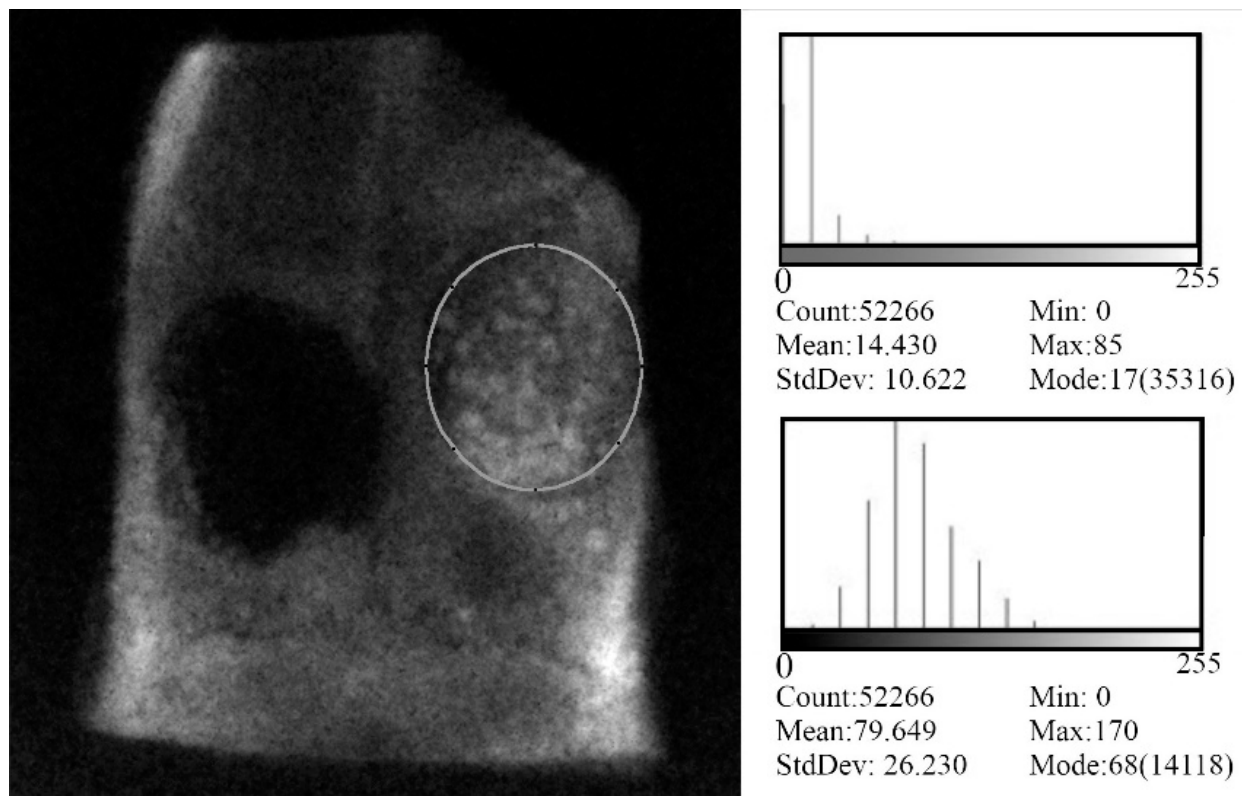

Figure 4. Evaluation of the radiographic bone density and Histogram, 9 weeks after treatment and after excision of bone defects.

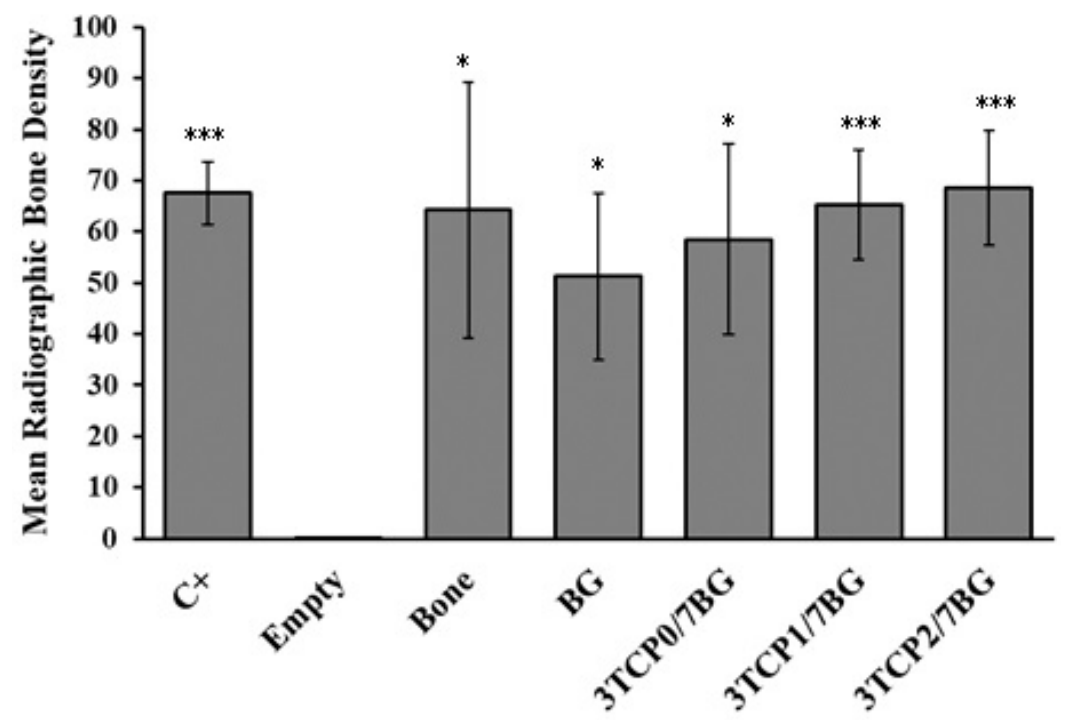

Figure 5. Radiographic bone density of excised bone defects and non-manipulated bone (positive control, $\mathrm{C}+$ ) evaluated after 9 weeks post-implantation. The figure represents the mean and standard error of at least 5 independent experiments. Statistically significant differences were obtained between the empty defect and the other groups. These differences are identified with the use of * that represents $p<0.05$ and ${ }^{* * *}$ that represents $p<0.001$. 


\subsection{Histological Analysis}

Figure 6 shows histological representative images (H\&E staining) of the study groups 9 weeks after the treatment and excision. The images of empty bone defects reveal a slight formation of regenerated cancellous bone in the edge of the defect (Figure 6a). In turn, in the BG group (Figure 6b) small islands of osteoid and bone tissue within a capsule are clearly noticed.


Figure 6. Histological images (H\&E staining) of bone defects 9 weeks after treatment: (a) empty defect; and defects filled with: (b) BG; (c) 3TCP0/7BG; (d) 3TCP1/7BG; (e) 3TCP2/7BG. The Figure shows representative images of at least 5 independent experiments.

The formation of new osteoid and mature bone tissue with many osteoblasts and osteoclasts can be observed. On the other hand, in all experimental groups filled with composites, the formation of new bone tissue with vessels with a pattern of osteogenesis in the defect, containing many of osteoblasts cells could be observed (Figure $6 \mathrm{c}-\mathrm{e}$ ). It is worth noting that, in comparison to defects filled with 3TCP2/7BG (Figure 6e), when the bone defect was filled with 3TCP1/7BG, a larger amount of 
biomaterial remained non-reabsorbed (white spots) (Figure 6d). The complete absence of inflammation at 9 weeks after the treatment was a common feature to all studied groups.

\subsection{Histomorphometric Analysis}

Through the Von Kossa (VK) staining, the ability of the materials under study for stimulating osteoblastic differentiation was evaluated. In this assay, darker deposits correspond to greater amounts of deposited calcium which, in turn, is an indication of the extent of extracellular mineralization promoted by osteogenesis. Using image processing programs, this qualitative analysis can later give rise to quantitative data, allowing calculating the percentage of newly formed bone. Thus, Figures 6 and 7 represent, respectively, the qualitative and quantitative analysis of newly formed bone in samples excised 9 weeks after the mentioned treatments.
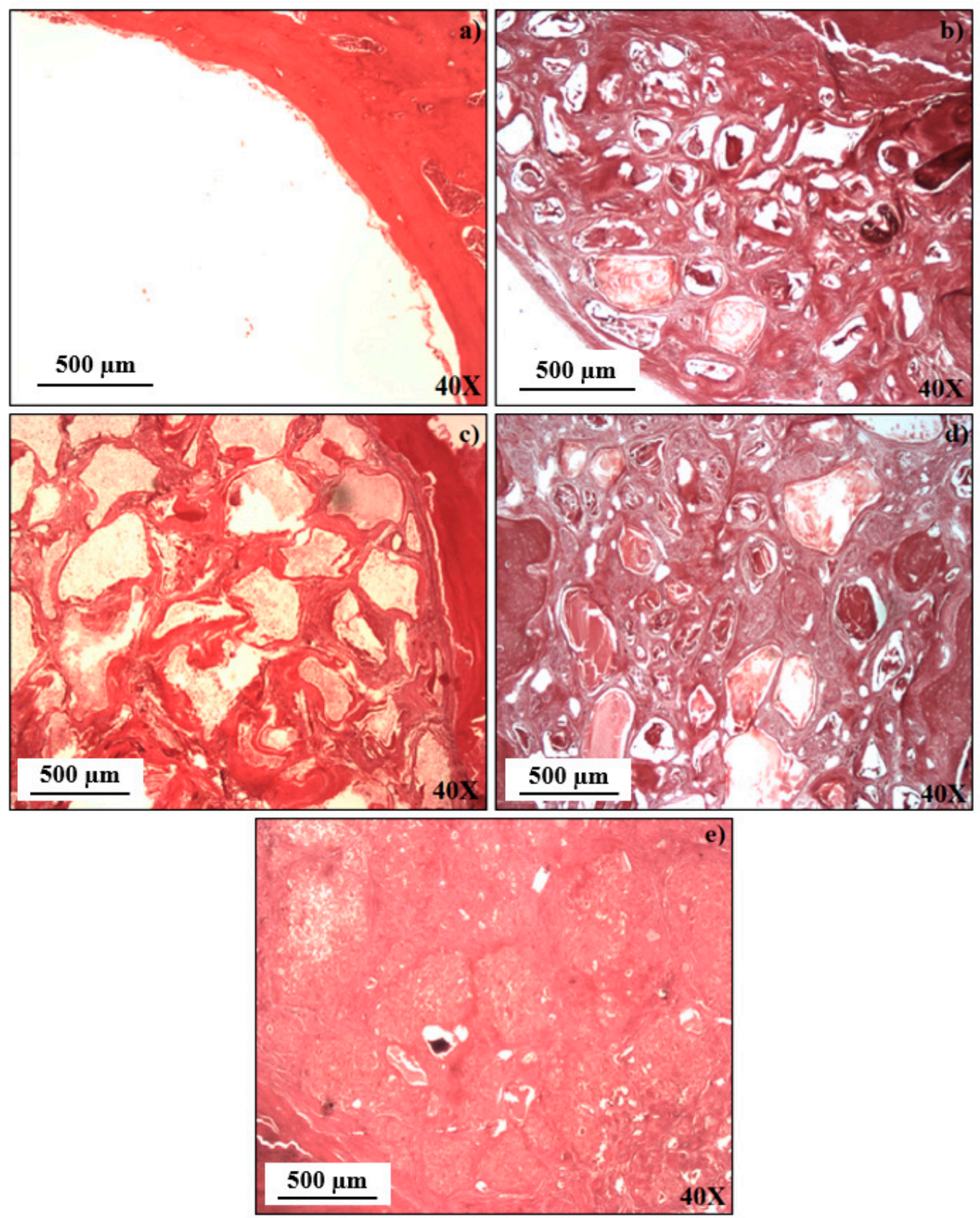

Figure 7. Histological images (VK staining) of bone defects 9 weeks after treatment and after excision: (a) empty defect; and defects filled with: (b) BG; (c) 3TCP0/7BG; (d) 3TCP1/7BG; (e) 3TCP2/7BG. The Figure shows representative images of at least 5 independent experiments. 
The percentages of newly formed bone in the created defects are displayed in Figure 8, which clearly shows the great advantage of filling bone defects with any of the investigated bone graft materials in comparison to the non-filled defects. As a matter of fact, only a very small amount of newly formed bone was measured in the empty defects.

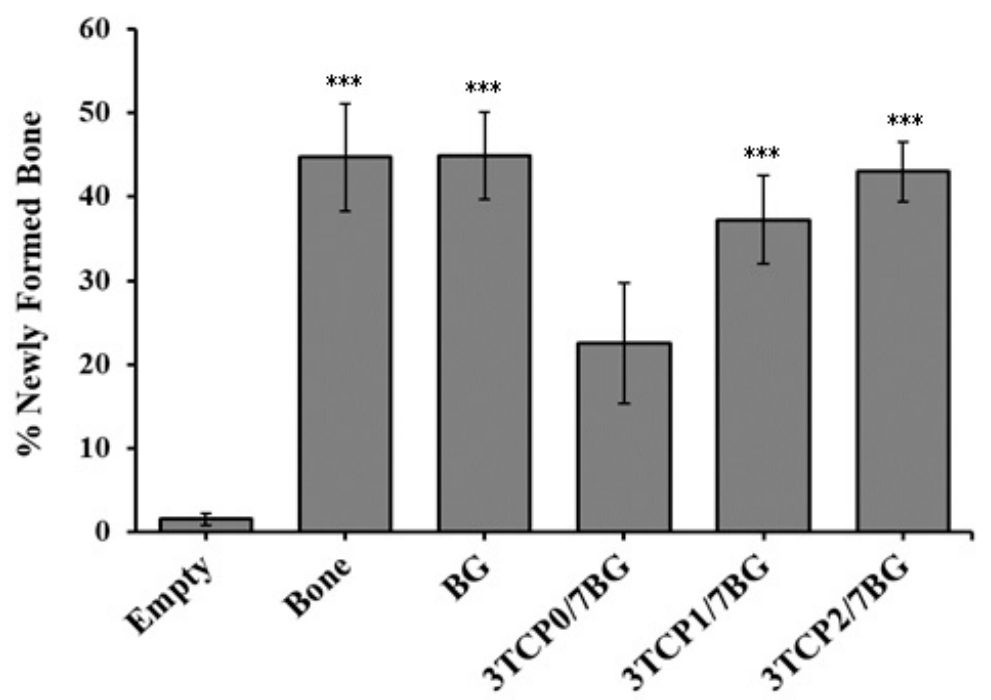

Figure 8. Percentages of newly formed bone in bone defects 9 weeks after treatment and after excision. The Figure represents the mean \pm standard deviation of at least 5 independent experiments. Significant differences relative to empty group are identified with the use of ${ }^{* * *}$ that represents $p<0.001$.

Statistically significant differences were observed between the empty defect $(p<0.001)$ and all other experimental ones, with the exception of the defect filled with 3TCP0/7BG, where no statistically significant differences were observed. On the other hand, comparing the in vivo performance of the different composite bone graft materials, although there are no statistically significant differences, a tendency for an increase in the percentage of new bone formed as the percentage of dopants increases is observed.

Therefore, it can be concluded that the added biologically active inorganic ions $\left(\mathrm{Sr}^{2+}, \mathrm{Zn}^{2+}\right.$ and $\mathrm{Mn}^{2+}$ ) stimulate the interactions between the composite granules and surrounding cells/tissues, thus accelerating the processes of new bone formation and growth, and of healing the bone defects. Comparing the results obtained for the two composites 3TCP1/7BG and 3TCP2/7BG, the osteogenic potential was slightly higher for the latest one, which can be attributed to its higher concentration in $\mathrm{Sr}^{2+}$ and $\mathrm{Zn}^{2+}[28,29]$. In accordance, other studies have demonstrated that the replacement of $\mathrm{Ca}^{2+}$ by $\mathrm{Sr}^{2+}$ in the crystalline structure of calcium phosphates enhances their osteointegration [28,29], while reducing the reabsorption by osteoclasts, preventing osteoporosis. Other Sr-derived benefits include enhanced bone formation and mechanical resistance, contributing to reducing the risk of fractures [21,33,34]. Regarding zinc, its stimulating roles in bone metabolism, cell adhesion [39], bone formation, regeneration and mineralization are well-known [29,32-35]. Its inhibitory bacterial growth effect at the surgical site is another important feature for avoiding infections and accelerating wound healing [37-39]. On the other hand, the molar concentration of Mn was maintained equal in both metal-doped bone graft materials because of the limited useful ranges of Mn incorporation in terms of in vitro biological benefits that can be extracted this doping agent [46].

\section{Conclusions}

The aim of this study was to understand the influence of doping the $\beta$-TCP component in the synthetic bone graft composites on the in vivo performance in comparison to empty defects, and non-manipulated bone, bone morsels, and FastOs ${ }^{\circledR} \mathrm{BG}$ used as controls. The results presented and discussed clearly show that all the synthetic biomaterials tested were effective in inducing the 
bone regeneration. However, the biological response of composite bone graft materials tended to increase with increasing doses of the doping elements, showing that the level of doping is a relevant factor in determining bone density and amount of new bone formed. Accordingly, the best performing composite material [3TCP2/7BG] was as effective as bone morsels and FastOs ${ }^{\circledR}$ BG used as control materials. Moreover, after 9 weeks post-implantation, the bone defects regenerated with both 3TCP2/7BG and FastOs ${ }^{\circledR}$ BG can hardly be distinguished from the non-manipulated bone. These results are very encouraging towards further testing the most performing materials in future clinical trials. On the basis of the results presented in this study, it appears that doping the $\beta$-TCP component in the synthetic bone graft composites may be effective in inducing bone regeneration. This finding confirms that doping the bone graft materials with suitable doses of therapeutic ions is a good strategy towards transposing them to biomedical applications in humans.

Author Contributions: Authors M.M.F., A.F.B., E.C., A.M.A. and M.F.B. designed the in vivo studies and contributed to the preparation of the first draft of the related parts of the paper. Authors D.B., I.C.P. and J.M.F.F., designed and prepared the bone graft materials and contributed to the preparation of the first draft of the related parts of the paper. Authors M.M.F., A.F.B., M.J.A, and L.C. were responsible for the histological analysis. Authors A.M.A and M.F.B. were responsible for the animal care before, during, and after implantation, and contributed for drafting the related parts of the paper. Authors M.M.F., A.F.B, D.B., and I.C.P. were in charge of plotting the experimental data and preparing all the Figures. Authors A.F.B., and A.S.P. were responsible for the statistical analysis of the data. All authors revised the paper critically for intellectual content and approved the final version. All authors agree to be accountable for the work and to ensure that any questions relating to the accuracy and integrity of the paper are investigated and properly resolved.

Funding: Thanks are due to CICECO-Aveiro Institute of Materials (UID/CTM/50011/2013) project funded by FEDER funds through the Operational Programme Competitiveness Factors (COMPETE 2020) and the Portuguese Foundation for Science and Technology (FCT). The authors also would like to thank FCT (Portugal) by the financing of PEst-UID/NEU/04539/2013 and FEDER-COMPETE (FCOMP-01-0124-FEDER-028417 and POCI-01-0145-FEDER-007440).

Conflicts of Interest: The authors declare no conflict of interest. The funders had no role in the design of the study; in the collection, analyses, or interpretation of data; in the writing of the manuscript, or in the decision to publish the results.

\section{References}

1. Planell, J.A.; Navarro, M. Challenges of bone repair. In Bone Repair Biomaterials; Planell, J.A., Best, M., Lacroix, D., Merolli, A., Eds.; Woodhead Publishing Limited: Cambrigde, UK, 2009; pp. 3-6, ISBN 978-1-84569-385-5.

2. Bohner, M. Resorbable biomaterials as bone graft substitutes. Mater. Today 2010, 13, 24-30. [CrossRef]

3. Sheikh, Z.; Najeeb, S.; Khurshid, Z.; Verma, V.; Rashid, H.; Glogauer, M. Biodegradable materials for bone repair and tissue engineering applications. Materials 2015, 8, 5744-5794. [CrossRef] [PubMed]

4. Schimandle, J.H.; Boden, S.D. Bone substitutes for lumbar fusion:present and future. Oper. Tech. Orthop. 1997, 7, 60-67. [CrossRef]

5. O’Brien, F.J. Biomaterials \& scaffolds for tissue engineering. Mater. Today 2011, 14, 88-95. [CrossRef]

6. Brown, W.E.; Chow, L.C. A new calcium phosphate water setting cement. Cem. Res. Progress Westerv. Am. Ceram. Soc. 1986, 352.

7. Dorozhkin, S.V. Calcium orthophosphates. J. Mater. Sci. 2007, 42, 1061-1095. [CrossRef]

8. Dorozhkin, S.V. Calcium orthophosphates in dentistry. J. Mater. Sci. Mater. Med. 2013, 24, $1335-1363$. [CrossRef]

9. Vallet-Regí, M. Ceramics for medical applications. J. Chem. Soc. Dalton Trans. 2001, 97-108. [CrossRef]

10. Dorozhkin, S.V. Calcium orthophosphate bioceramics. Eurasian Chem. J. 2010, 12, 247-258. [CrossRef]

11. Albrektsson, T.; Johansson, C. Osteoinduction, osteoconduction and osseointegration. Eur. Spine J. 2001, 10, 96-101. [CrossRef]

12. Nandi, S.K.; Roy, S.; Mukherjee, P.; Kundu, B.; Basu, D. Orthopaedic applications of bone graft \& graft substitutes: A review. Indian J. Med. Res. 2010, 132, 15-30.

13. Sheikh, Z.; Abdallah, M.N.; Hanafi, A.A.; Misbahuddin, S.; Rashid, H.; Glogauer, M. Mechanisms of in vivo degradation and resorption of calcium phosphate based biomaterials. Materials 2015, 8, 7913-7925. [CrossRef] [PubMed] 
14. Yuan, H.; Fernandes, H.; Habibovic, P.; de Boer, J.; Barradas, A.M.C.; de Ruiter, A.; Walsh, W.R.; van Blitterswijk, C.A.; de Bruijn, J.D. Osteoinductive ceramics as a synthetic alternative to autologous bone grafting. Proc. Natl. Acad. Sci. USA 2010, 107, 13614-13619. [CrossRef] [PubMed]

15. Oh, K.J.; Ko, Y.B.; Jaiswal, S.; Whang, I.C. Comparison of osteoconductivity and absorbability of beta-tricalcium phosphate and hydroxyapatite in clinical scenario of opening wedge high tibial osteotomy. J. Mater. Sci. Mater. Med. 2016, 27, 1-7. [CrossRef]

16. Ishack, S.; Mediero, A.; Wilder, T.; Ricci, J.L.; Cronstein, B.N. Bone regeneration in critical bone defects using three-dimensionally printed $\beta$-tricalcium phosphate/hydroxyapatite scaffolds is enhanced by coating scaffolds with either dipyridamole or BMP-2. J. Biomed. Mater. Res. Part B Appl. Biomater. 2017, 105, 366-375. [CrossRef] [PubMed]

17. Hashemibeni, B.; Dehghani, L.; Sadeghi, F.; Esfandiari, E.; Gorbani, M.; Akhavan, A.; Tahani, S.T.; Bahramian, H.; Goharian, V. Bone repair with differentiated osteoblasts from adipose-derived stem cells in hydroxyapatite/tricalcium phosphate in vivo. Int. J. Prev. Med. 2016, 2016. [CrossRef]

18. Li, B.; Liu, Z.; Yang, J.; Yi, Z.; Xiao, W.; Liu, X.; Yang, X.; Xu, W.; Liao, X. Preparation of bioactive $\beta$-tricalcium phosphate microspheres as bone graft substitute materials. Mater. Sci. Eng. C 2017, 70, 1200-1205. [CrossRef]

19. Cheng, L.; Wang, T.; Zhu, J.; Cai, P. Osteoinduction of Calcium Phosphate Ceramics in Four Kinds of Animals for 1 Year: Dog, Rabbit, Rat, and Mouse. Transplant. Proc. 2016, 48, 1309-1314. [CrossRef]

20. Gan, Y.; Dai, K.; Zhang, P.; Tang, T.; Zhu, Z.; Lu, J. The clinical use of enriched bone marrow stem cells combined with porous beta-tricalcium phosphate in posterior spinal fusion. Biomaterials 2008, 29, 3973-3982. [CrossRef]

21. Pina, S.; Vieira, S.I.; Rego, P.; Torres, P.M.C.; da Cruz E Silva, O.A.B.; da Cruz E Silva, E.F.; Ferreira, J.M.F. Biological responses of brushite-forming Zn- and ZnSr- substituted beta-tricalcium phosphate bone cements. Eur. Cell. Mater. 2010, 20, 162-177. [CrossRef]

22. Ferreira, M.M.; Brito, A.F.; Marques, C.F.; Freitas, L.F.; Carrilho, E.; Abrantes, A.M.; Pires, A.S.; Aguiar, M.J.; Carvalho, L.; Botelho, M.F.; et al. Can the regenerative potential of an alkali-free bioactive glass composition be enhanced when mixed with resorbable $\beta$-TCP? Ceram. Int. 2017, 44, 5025-5031. [CrossRef]

23. Goel, A.; Kapoor, S.; Rajagopal, R.R.; Pascual, M.J.; Kim, H.W.; Ferreira, J.M.F. Alkali-free bioactive glasses for bone tissue engineering: A preliminary investigation. Acta Biomater. 2012, 8, 361-372. [CrossRef] [PubMed]

24. Cortez, P.P.; Brito, A.F.; Kapoor, S.; Correia, A.F.; Atayde, L.M.; Dias-Pereira, P.; Maurício, A.C.; Afonso, A.; Goel, A.; Ferreira, J.M.F. The in vivo performance of an alkali-free bioactive glass for bone grafting, FastOs ${ }^{\circledR}$ BG, assessed with an ovine model. J. Biomed. Mater. Res. Part B Appl. Biomater. 2017, 105, 30-38. [CrossRef] [PubMed]

25. Kansal, I.; Reddy, A.; Muñoz, F.; Choi, S.J.; Kim, H.W.; Tulyaganov, D.U.; Ferreira, J.M.F. Structure, biodegradation behavior and cytotoxicity of alkali-containing alkaline-earth phosphosilicate glasses. Mater. Sci. Eng. C 2014, 44, 159-165. [CrossRef] [PubMed]

26. Kapoor, S.; Semitela, Â.; Goel, A.; Xiang, Y.; Du, J.; Lourenço, A.H.; Sousa, D.M.; Granja, P.L.; Ferreira, J.M.F. Understanding the composition-structure-bioactivity relationships in diopside $\left(\mathrm{CaO} \cdot \mathrm{MgO} \cdot 2 \mathrm{SiO}_{2}\right)$-tricalcium phosphate $\left(3 \mathrm{CaO} \cdot \mathrm{P}_{2} \mathrm{O}_{5}\right)$ glass system. Acta Biomater. 2015, 15, 210-226. [CrossRef]

27. Brito, A.F.; Antunes, B.; dos Santos, F.; Fernandes, H.R.; Ferreira, J.M.F. Osteogenic capacity of alkali-free bioactive glasses. In vitro studies. J. Biomed. Mater. Res. Part B Appl. Biomater. 2017, 105, 2360-2365. [CrossRef]

28. Stewart, G.J. The Skeletal and Muscular Systems; Chealsea House Publishers: New York, NY, USA, 2004; Volume 53, ISBN 9788578110796.

29. Zofková, I.; Nemcikova, P.; Matucha, P. Trace elements and bone health. Clin Chem Lab Med 2013, 51, 1-7. [CrossRef] [PubMed]

30. Shepherd, J.H.; Shepherd, D.V.; Best, S.M. Substituted hydroxyapatites for bone repair. J. Mater. Sci. Mater. Med. 2012, 23, 2335-2347. [CrossRef]

31. LeGeros, R.; Lin, S.; LeGeros, J.; Cazalbou, S.; Combes, C.; Dupin-Roger, I. Strontium Ranelate Treatment Preserves Bone Crystal Characteristics and Bone Mineral Reactivity. Osteoporos. Int. 2004, 15, S116-S117.

32. Luo, X.; Barbieri, D.; Davison, N.; Yan, Y.; De Bruijn, J.D.; Yuan, H. Zinc in calcium phosphate mediates bone induction: In vitro and in vivo model. Acta Biomater. 2014, 10, 477-485. [CrossRef] 
33. Meunier, P.J.; Roux, C.; Seeman, E.; Ortolani, S.; Badurski, J.E.; Spector, T.D.; Cannata, J.; Balogh, A.; Lemmel, E.-M.; Pors-Nielsen, S.; et al. The Effects of Strontium Ranelate on the Risk of Vertebral Fracture in Women with Postmenopausal Osteoporosis. N. Engl. J. Med. 2004, 350, 459-468. [CrossRef]

34. Marie, P.J.; Ammann, P.; Boivin, G.; Rey, C. Mechanisms of action and therapeutic potential of strontium in bone. Calcif. Tissue Int. 2001, 69, 121-129. [CrossRef] [PubMed]

35. Yamaguchi, M.; Yamaguchi, R. Action of zinc on bone metabolism in rats. Increases in alkaline phosphatase activity and DNA content. Biochem. Pharmacol. 1986, 35, 773-777. [CrossRef]

36. Ito, A.; Otsuka, M.; Kawamura, H.; Ikeuchi, M.; Ohgushi, H.; Sogo, Y.; Ichinose, N. Zinc-containing tricalcium phosphate and related materials for promoting bone formation. Curr. Appl. Phys. 2005, 5, 402-406. [CrossRef]

37. Kawamura, H.; Ito, A.; Miyakawa, S.; Layrolle, P.; Ojima, K.; Ichinose, N.; Tateishi, T. Stimulatory effect of zinc-releasing calcium phosphate implant on bone formation in rabbit femora. J. Biomed. Mater. Res. 2000, 50, 184-190. [CrossRef]

38. Chen, D.; Waite, L.C.; Pierce, W.M. In vitro effects of zinc on markers of bone formation. Biol. Trace Elem. Res. 1999, 68, 225-234. [CrossRef]

39. Webster, T.J.; Ergun, C.; Doremus, R.H.; Bizios, R. Hydroxylapatite with substituted magnesium, zinc, cadmium, and yttrium. II. Mechanisms of osteoblast adhesion. J. Biomed. Mater. Res. 2002, 59, 312-317. [CrossRef]

40. Lang, C.; Murgia, C.; Leong, M.; Tan, L.; Perozzi, G.; Knight, D.; Ruffin, R.; Zalewski, P. Anti-inflammatory effects of zinc and alterations in zinc transporter mRNA in mouse models of allergic inflammation. Am. J. Physiol. Lung Cell. Mol. Physiol. 2007, 292, 577-584. [CrossRef]

41. Lansdown, A.B.G.; Mirastschijski, U.; Stubbs, N.; Scanlon, E.; Ågren, M.S. Zinc in wound healing: Theoretical, experimental, and clinical aspects. Wound Repair Regen. 2007, 15, 2-16. [CrossRef]

42. Söderberg, T.A.; Sunzel, B.; Holm, S.; Elmros, T.; Hallmans, G.; Sjöberg, S. Antibacterial effect of zinc oxide in vitro. Scand. J. Plast. Reconstr. Surg. Hand Surg. 1990, 24, 193-197. [CrossRef]

43. Armulik, A.; Svineng, G.; Wennerberg, K.; Fässler, R.; Johansson, S. Expression of integrin subunit beta1B in integrin beta1-deficient GD25 cells does not interfere with alphaVbeta3 functions. Exp. Cell Res. 2000, 254, 55-63. [CrossRef] [PubMed]

44. Cashman, K.; Flynn, A. Trace elements and bone metabolism. Bibl Nutr Dieta 1998, 54, 150-164.

45. Mayer, I.; Diab, H.; Reinen, D.; Albercht, C. Manganese in apatites, chemical, ligand-field and electron paramagnetic resonance spectroscopy studies. J. Mater. Sci. 1993, 28, 2428-2432. [CrossRef]

46. Torres, P.; Vieira, S.; Cerqueira, R.; Pina, S.; Da Cruz Silva, B.; Abrantes, J.; Ferreira, J. Effects of Mn-doping on the structure and biological properties of $\beta$-tricalcium phosphate. J. Inorg. Biochem. 2014, 136, 57-66. [CrossRef] [PubMed]

47. Hench, L.L.; Splinter, R.J.; Allen, W.C.; Greenlee, T.K. Bonding mechanisms at the interface of ceramic prosthetic materials. J. Biomed. Mater. Res. 1971, 5, 117-141. [CrossRef]

48. Hench, L.L.; Day, D.E.; Höland, W.; Rheinberger, V.M. Glass and Medicine. Int. J. Appl. Glass Sci. 2010, 1, 104-117. [CrossRef]

49. Sepulveda, P.; Jones, J.R.; Hench, L.L. In vitro dissolution of melt derived 45 S5 and sol-gel derived 58 S bioactive glasses. Biomed. Mater. Res. 2002, 61, 301-311. [CrossRef] [PubMed]

50. Jones, J.R. Reprint of: Review of bioactive glass: From Hench to hybrids. Acta Biomater. 2015, 23, S53-S82. [CrossRef]

51. Chen, Q.Z.; Thompson, I.D.; Boccaccini, A.R. 45S5 Bioglass ${ }^{\circledR}$-derived glass-ceramic scaffolds for bone tissue engineering. Biomaterials 2006, 27, 2414-2425. [CrossRef] [PubMed]

52. Clupper, D.C.; Hench, L.L. Crystallization kinetics of tape cast bioactive glass 45S5. J. Non-Cryst. Solids 2003, 318, 43-48. [CrossRef]

53. Lefebvre, L.; Chevalier, J.; Gremillard, L.; Zenati, R.; Thollet, G.; Bernache-Assolant, D.; Govin, A. Structural transformations of bioactive glass $45 \mathrm{~S} 5$ with thermal treatments. Acta Mater. 2007, 55, 3305-3313. [CrossRef]

54. Bretcanu, O.; Chatzistavrou, X.; Paraskevopoulos, K.; Conradt, R.; Thompson, I.; Boccaccini, A.R. Sintering and crystallisation of 45 S5 Bioglass ${ }^{\circledR}$ powder. J. Eur. Ceram. Soc. 2009, 29, 3299-3306. [CrossRef]

55. Kapoor, S.; Goel, A.; Pascual, M.J.; Ferreira, J.M.F. Alkali-free bioactive diopside-tricalcium phosphate glass-ceramics for scaffold fabrication: Sintering and crystallization behaviours. J. Non-Cryst. Solids 2016, 432, 81-89. [CrossRef] 
56. Goel, A.; Kapoor, S.; Tilocca, A.; Rajagopal, R.R.; Ferreira, J.M.F. Structural role of zinc in biodegradation of alkali-free bioactive glasses. J. Mater. Chem. B 2013, 1, 3073-3082. [CrossRef]

57. Kapoor, S.; Goel, A.; Tilocca, A.; Dhuna, V.; Bhatia, G.; Dhuna, K.; Ferreira, J.M.F. Role of glass structure in defining the chemical dissolution behavior, bioactivity and antioxidant properties of zinc and strontium co-doped alkali-free phosphosilicate glasses. Acta Biomater. 2014, 10, 3264-3278. [CrossRef] [PubMed]

58. Kapoor, S.; Goel, A.; Pascual, M.J.; Ferreira, J.M.F. Thermo-mechanical behaviour of alkali free bioactive glass-ceramics co-doped with strontium and zinc. J. Non-Cryst. Solids 2013, 375, 74-82. [CrossRef]

59. Olhero, S.M.; Fernandes, H.R.; Marques, C.F.; Silva, B.C.G.; Ferreira, J.M.F. Additive manufacturing of 3D porous alkali-free bioactive glass scaffolds for healthcare applications. J. Mater. Sci. 2017, 52, 12079-12088. [CrossRef]

60. Kannan, S.; Goetz-Neunhoeffer, F.; Neubauer, J.; Pina, S.; Torres, P.M.C.; Ferreira, J.M.F. Synthesis and structural characterization of strontium- and magnesium-co-substituted $\beta$-tricalcium phosphate. Acta Biomater. 2010, 6, 571-576. [CrossRef]

61. Jillavenkatesa, A.; Condrate, R.A. The Infrared and Raman Spectra of $\beta$-and $\alpha$-Tricalcium Phosphate $\left(\mathrm{Ca}_{3}\left(\mathrm{Po}_{4}\right)_{2}\right)$. Spectrosc. Lett. 1998, 31, 1619-1634. [CrossRef]

62. Berzina-Cimdina, L.; Borodajenko, N. Research of Calcium Phosphates Using Fourier Transform Infrared Spectroscopy. In Infrared Spectroscopy-Materials Science, Engineering and Technology; IntechOpen: London, UK, 2012; pp. 123-148, ISBN 978-953-51-0537-4.

63. Meejoo, S.; Maneeprakorn, W.; Winotai, P. Phase and thermal stability of nanocrystalline hydroxyapatite prepared via microwave heating. Thermochim. Acta 2006, 447, 115-120. [CrossRef]

(C) 2018 by the authors. Licensee MDPI, Basel, Switzerland. This article is an open access article distributed under the terms and conditions of the Creative Commons Attribution (CC BY) license (http:/ / creativecommons.org/licenses/by/4.0/). 